\title{
Research on Marketing Strategies of Library Discipline Service Under the Background of "Double First-Class" University Project
}

\author{
Ping Zhou ${ }^{1}$, Ya Chen ${ }^{2, *}$ \\ ${ }^{1}$ Library of Nanjing Forest Police College, Nanjing, China \\ ${ }^{2}$ School of Information Management, Nanjing University, Nanjing, China \\ *Corresponding author
}

\begin{abstract}
Discipline service is essential part of library service to support the construction of "double first-class". Strategies including decision support service in this research. Combined with the new trend of library discipline service, it is supposed that the discipline service object of "double first-class" university library should be personalized into different groups, such as scientific research personnel, decision maker and so on. The discipline service pattern can be improved through carrying out of embedded and dynamic tracking service based on the theory of research life cycle. On this basis, user portrayal is introduced to the discipline service marketing combined with the personalized and dynamic tracking service pattern and strategies of library service marketing, taking an example of Southeast University library, are also provided in this study under the background of the construction of "double first-class".
\end{abstract}

Keywords: Discipline service, User portrayal, Service marketing, "Double First-Class" University project

\section{INTRODUCTION}

In 2015, the State Council issued the "Overall Plan for Promoting the Construction of World-class Universities and First-class Disciplines in an Overall Plan", clearly proposing the "double-first-class" construction goal of building first-class universities and first-class disciplines "guided by Chinese characteristics and world-class, supported by innovation-driven development strategies and serving the economy and society. [1]Library is an important part of colleges and universities, of which subject service is an important embodiment of the university library's service to the discipline construction and scientific research activities of the university, and is an important support and guarantee for the construction of "double first-class" colleges and universities [2].Traditional subject services in university libraries mainly focus on information consultation, sci-tech novelty retrieval, information retrieval, etc. The service objects are inaccurate, the service contents are lack of innovation, the service methods are relatively passive, and they do not go deep into specific subjects and researchers [3].Under the background of the construction of "double first-class" universities, the subject service of the library needs to change the traditional service mode and content, from "rough" to "precise" and from "passive" to "active", so as to improve the accuracy and precision of the service and help the teaching and scientific research of the school and the construction of "double first-class" in an all-round way [4].

\section{NEW REQUIREMENTS OF "DOUBLE FIRST-CLASS" CONSTRUCTION ON LIBRARY SUBJECT SERVICE IN-DEPTH PERSONALIZED SERVICE}

\footnotetext{
Discipline is the foundation of "double first-class" construction.In the process of "double first-class" construction, colleges and universities pay more attention to and strengthen the construction of superior disciplines. At the same time, they also put forward new requirements for library discipline services, such as personalized demand for service content and form, depth of service, etc. Under the background of "double first-class" construction, library subject service should match the demands of university professional construction, refine the content and form of service according to subject differences, and provide personalized service for different subjects. In addition, subject service objects are expanded and extended to provide different service contents for different service object groups and provide deep service contents for demands of different groups.
} 


\subsection{Attaching Importance to User's Initiative}

Discipline and professional personnel training is the key to First-class discipline construction, first-class colleges and universities should have first-class undergraduate education [5].Library subject service should strengthen the cultivation of undergraduate scientific literacy and scientific research ability. University library needs to research users' needs and pay attention to users' subjective initiative in subject service. In the construction of "double first-class" universities, the important position of personnel training, especially undergraduate education, has been highlighted. Therefore, the subject service of university libraries should deepen the content of teaching support services in the future, which has also become one of the breakthrough points in improving the subject service of university libraries.

\subsection{Integration into Scientific Research Life Cycle}

At present, specialized personnel are assigned to be responsible for discipline services in universities, but the awareness of active service needs to be strengthened, especially embedded services for the whole process of scientific research of scientific researchers, i.e. scientific research support services based on the scientific research life cycle, such as preliminary data collection, subsequent data analysis, preservation and value re-creation of scientific research data, scientific research awards, etc. At present, scientific research support services at home and abroad include scientific research data management, open access, academic publishing, research impact measurement, research navigation, research consultation, and research tool recommendation [6].

\section{DEVELOPMENT TREND OF SUBJECT SERVICE IN UNIVERSITY LIBRARIES}

\subsection{Service Granularity Refinement}

In order to promote the ranking of schools and specialties, universities attach importance to the support for key specialties under the background of "double first-class" construction. The library is not only the document providing organization of the school, but also the indispensable intermediary organization that affects the development of the school. Under the background of "double first-class", the service pattern of the university library is larger, serving the disciplines and cross-disciplines that the school gives priority to, and supporting the development of disciplines from the macro level.

\subsection{Deepening of Service Content}

Subject service of university library is the core service to support the "double first-class" construction of the school. Relying on the resource construction of the library, developing subject service for teaching and scientific research of all teachers and students is an important service content to improve the scientific research level of the school and subject construction [7].In the future, on the basis of adhering to basic services, the development of university libraries should cooperate with and actively participate in the school's "double first-class" construction in terms of policies, mechanisms and decisions, provide services for personnel training and academic research in terms of knowledge, intelligence and resources, give full play to the core competitiveness of libraries, and provide decision-making services, data services and space services for users.

\subsection{Embedded and Dynamic Tracing of Service Forms}

Around the whole scientific research process of scientific researchers, embedded and dynamic tracking services are carried out to provide real-time service support for scientific researchers. Based on the life cycle of scientific research, it provides dynamic tracking services to scientific researchers, participates in scientific research activities of scientific researchers and provides scientific research support services to help build a "double first-class". In addition, the subject service content of university libraries should be tracked dynamically with the development of disciplines and specialties in universities, pay close attention to the construction of disciplines and specialties in universities in a timely manner, adjust the service content and strategies in real time, and help the construction objectives and tasks of "double first-class" universities.

\subsection{Library of Southeast University Discipline Service Marketing Analysis}

In the "double first-class" construction plan of Southeast University, it is proposed to focus on the construction of 15 first class disciplines (groups) including biomedical engineering, transportation engineering, architecture, electronic science and technology. From the discipline construction, personnel training, scientific research and other aspects to carry out, the Southeast University get through the first-class discipline (group) to drive the overall coordinated development of the school [8]. 


\subsection{Service Location and Type}

The development and marketing of library services are fundamentally based on users' needs, that is, to provide accurate service contents and forms according to users' personalized needs. The library of Southeast university has developed two service types of "scientific research support" and "teaching support" according to service objectives. The service types of the two major types of different objectives are set up with specific service contents from the perspectives of resource guarantee, scientific research and teaching service assistance, interaction and communication [9].

\subsection{Service Contents and Methods}

Under the background of "double first-class" construction, the demand for diversity of subject service contents and forms in libraries is more intense. It is one of the trends of subject service for university libraries to provide diversified service contents for different groups and different mission objectives. At the same time, it provides academic evaluation services such as competitiveness analysis, scientific research performance evaluation, discipline evaluation tools, discipline situation analysis, etc. to meet the decision-making needs of schools. In addition, academic support, subject information portal, face-to-face with editor-in-chief and other academic help services will be provided.

\subsection{Service Features and Evaluation}

An important trend of development of subject services in university libraries lies in the provision of dynamic tracking services, that is, embedding user groups to dynamically track changes in their needs, and adjusting the content and form of services according to the changes in needs to better meet the needs of user groups. Subject service in Southeast University library is based on the service contents of a certain link in the scientific research process in traditional subject service (such as sci-tech novelty search, check and quotation). According to the theory of scientific research life cycle, scattered and disordered subject service is integrated into a dynamic tracking service process embedded in the scientific research process, i.e. embedded scientific researchers and then dynamically tracking the changes in demand in the whole scientific research process, and targeted subject service is carried out according to the differences in information demand in different stages of the scientific research process. In addition to checking and quoting services for the application phase of the subject, it also provides full-process services for paper submission and later scientific research awards, i.e. providing dynamic tracking services based on scientific research process.
Southeast University library will assess librarians according to the effect of service. As a quantitative indicator for selecting outstanding librarians, subject service is no longer based on form, but should be truly integrated into the life cycle of teaching and scientific research. Librarians are no longer just librarians, and can join scientific research teams to improve their scientific research level.

\section{UNIVERSITY LIBRARY SUBJECT SERVICE MARKETING STRATEGIES}

\subsection{Refine Service Groups Based on User Portraits}

Precision marketing was first proposed by Philip Kotler in 2005. It refers to the use of modern technology to precisely locate target groups and establish personalized communication systems to expand the scope of marketing. The emergence of precision marketing solves the contradiction between product homogeneity and personalized user needs. Precision marketing is usually closely related to information technology, which can be used to promote marketing and maximize benefits [10].In the specific implementation process of user portrait research in precision marketing, the three-layer virtual model of user data is mainly constructed. Firstly, the objectives and tasks of constructing user portrait are confirmed to guide the collection direction of user attributes, and the basic data layer is constructed. Under the guidance of the objectives, user attributes are collected, including static attributes, dynamic attributes, consumption attributes and psychological attributes. Secondly, data processing is to extract, label and model user features, classify user groups on this basis, and divide users into more detailed groups according to different division standards. The third layer, the user layer is the service layer, which is also the application layer formed by user portraits. User behavior analysis and prediction are carried out through user tags, and personalized recommendation services are carried out on this basis, so as to realize the accuracy of product and service marketing.

\subsection{Dynamic Tracking and Service Based on User Behavior}

The subject service construction of university library should pay more attention to the study of library user characteristics and behaviors, collect and analyze library user behavior data in all directions, and provide more accurate and personalized service contents for different user groups, so as to improve the overall service level of the library and provide important resources and service guarantee for the construction of double-class universities. A new generation of library management system, unified authentication and 
management of user basic data and behavior data, tracking changes in user needs, through the subdivision of users to provide accurate services [11].The library can obtain all kinds of information of users using the library in real time. In addition to the basic personal information of users, it also includes the usage frequency of resources, scientific research and resource usage time, information acquisition channel preferences, borrowing preferences, and the usage of digital resources, etc. we should collect all-round and multi-level collection and acquisition of library user behavior data, of which users' research interest is also an important collection content. All-round data tracking and dynamic tracking of library users, with the help of unified management and analysis, can obtain diversified usage habits and preferences of users, and can more accurately predict user behavior.

\subsection{Active Service Forms Embedded in Scientific Research Process}

Under the background of "double first-class" construction, colleges and universities will formulate development policies and strategies according to the actual situation of their own universities, including the key development of disciplines and specialties, the direction of talent introduction, etc. In the future development of library discipline services, they should closely conform to the direction of "double first-class" construction of universities. Based on this, they should grasp the direction and focus of discipline services, and on the basis of ensuring the service of ordinary users, they should make in-depth analysis on the attributes of key development disciplines and research team personnel. Then the libraries will be mining its information needs and predicting its behavioral characteristics, and on this basis, providing proactive, targeted and embedded subject services, such as a series of personalized subject services with strong professional pertinence and high subject relevance, or novelty search services for early-stage topics around the research life cycle, document retrieval services in the research process, and scientific data management after the research is completed, so as to realize accurate marketing of subject services.

\section{CONCLUSION}

User research has always been the foundation of library service. Under the background of "double first-class" construction, the expansion of library service objects has changed its service contents and methods. Library subject service is oriented by the "double first-class" construction goal, which refines the user group of service objects and carries out personalized, embedded and dynamic tracking services. Subject service is an important service for university libraries to support the construction of "double first-class", and is also the core content of library function and service transformation. With the background of "double first-class" construction, university libraries actively participate in the development and planning of universities, which is of great significance for improving the status and core competitiveness of libraries and promoting the development of libraries. Therefore, the library can use the opportunity of "double first-class" construction to improve the level of subject service and user satisfaction through accurate marketing of subject service. At the same time, it will help the construction of "double first-class", give full play to the library's knowledge service function and enhance the library's core competitiveness.

\section{REFERENCES}

[1] Information on http://www.gov.cn/xinwen/2017-01/27/content _ 5163903.htm \# 1 .

[2] Yang Wei, Lin Jing, Huang Guofan, etc. Marketing Strategy of Subject Knowledge Service for "Double First-Class" Construction-Practice of Xiamen University Library. journal of academic libraries. 35(2017)74-79.

[3] Dong Tongqiang, Ma Xiufeng. Construction of Intelligent Subject Service Platform for University Libraries Integrating "Double First Class" Construction. Modern Intelligence.39(2019)97-103.

[4] Xiao Long. Research on Service Innovation Trend of University Libraries Supporting "Double First Class" Construction. journal of academic libraries. 36(2018)43-51.

\section{[5] Information on} www.moe.gov.cn/srcsite/A22/moe_843/201808/t201808 23_345987.html?from=timeline\&isappinstalled $=0$.

[6] Si Li, Zeng yueliang. survey and analysis of scientific research support services in world-class university libraries. library and information work.62(2018)30-41.

[7] Information on http://www.cashl.edu.cn/portal/saalforum4/reports/1/2$\%$ Е6\%9C\%B1\%Е5\%BC\%BA-\%Е5\%8F\%8С\%Е4\%B8 $\% 80 \%$ E6\%B5\%81\%Е8\%83\%8C\%Е6\%99\%AF\%Е4\% В8\%8B\%Е9\%АB\%98\%Е6\%A0\%A1\%Е5\%9B\%ВE\% E4\%B9\%A6\%E9\%A6\%86\%E5\%8F\%91\%E5\%B1\%95 $\% \mathrm{E} 5 \% 92 \% 8 \mathrm{C} \% \mathrm{E} 6 \% 8 \mathrm{C} \% 91 \% \mathrm{E} 6 \% 88 \% 98$.pdf.

[8] Li Yanmin. Accurate Marketing of University Digital Library Resource Services. Xi 'an: xidian University. (2014)

[9] Zhang Qing. Research on Subject Service Mode of University Library Based on Precision Marketing Concept-Taking Taizhou University Library of Nanjing 
Normal University as an Example. journal of library science. (2018)103-106.

[10] Qiu Huilin, Shao Bo. Construction of Accurate Service of University Library Based on User Portrait. University Library Work. (2018)70-74.

[11] Information on

http://www.seu.edu.cn/2018/0105/c124a206861/page.ht $\mathrm{m}$. 